\title{
RESEARCH PAPER \\ Agronomic performance of fig plants grown with different numbers of branches
}

\author{
Vander Mendonça, Francisco S.O. Silva, Anderson A. Alves, Elânia G.P. \\ Martins, Elizangela C. dos Santos, Wagner C. Farias, and Eduardo C. \\ Pereira
}

Federal Rural University of Semiarid (UFERSA), Department of Agrarian and Forest Sciences, Fitotecnia. Av. Francisco Mota, 572 - Bairro Costa e Silva, Mossoró-RN, CEP: 59.625-900, Brazil.

\begin{abstract}
V. Mendonça, F.S.O. Silva, A.A. Alves, E.G.P. Martins, E.C. dos. Santos, W.C. Farias, and E.C. Pereira. 2021. Agronomic performance of fig plants grown with different numbers of branches. Int. J. Agric. Nat. Resour. 14-20. Fig production and quality are associated with the number of branches per plant and may vary among regions according to the climatic conditions and crop management. In this work, we studied the influence of the number of branches per plant on the production and fruit quality of 'Roxo de Valinhos' figs under semiarid conditions. The experiment was carried out at the didactic orchard of Federal Rural University of Semiarid (UFERSA), Mossoró city, Rio Grande do Norte state, Brazil. Fig plants were grown with 6, 12, 18 , or 30 branches in a completely randomized block design with four replicates and four plants per plot. Plants without thinning were also cultivated as controls. The number of fruits per plant, productivity, fruit length, fruit diameter, and fruit weight were evaluated. Additionally, fruit firmness, titratable acidity (TA), soluble solids content (SS), maturation index (SSC/TA), and vitamin $\mathrm{C}$ content were analyzed. The results showed that plants cultivated with 12,18 , and 24 branches produced fruits with higher weight, more fruits per branch, and more fruits per plant and thus were more productive. Additionally, fruits showed a high vitamin $\mathrm{C}$ content and maturation index.
\end{abstract}

Keywords: Fruticulture, Ficus carica L., postharvest, productivity, pruning.

\section{Introduction}

Fig (Ficus carica L.) is a fruit tree belonging to the Moraceae family that has been used for centuries in Chinese medicine (Yang et al., 2015). A typical Mediterranean species, fig fruits are appreciated and have the potential to be exploited around the

Received Dec 13, 2019. Accepted Jan 25, 2021 Corresponding author: f_sidene@hotmail.com world, similar to common fruits such as peach, apple, and apricot (Gaaliche et al., 2011).

In Brazil, satisfactory conditions exist for fig cultivation, although this plant has been exploited without the use of innovations and technical improvements (Giacobbo et al., 2007). South and Southeast Brazil are the major fig-producing regions in Brazil, both for fresh consumption 
and industry. Because figs can adapt to different climatic conditions (Ramos et al., 2008), plants can also be grown in North and Northeast Brazil.

Although figs are grown in several regions with similar climatic conditions, studies on canopy training are still scarce. In other species, studies have shown that the optimal number of branches per plant can maintain a balance between production and fruit quality (Kim et al., 2017). Additionally, few studies have been carried out with exotic species in semiarid regions. Silva et al. (2017) found that figs from the 'Roxo de Valinhos' cultivar showed high quality under semiarid conditions.

In this work, we studied the influence of the number of branches per plant on fruit production and quality in 'Roxo de Valinhos' figs under semiarid conditions.

\section{Materials and Methods}

\section{Experimental location and plant growth conditions}

The experiment was carried out in two production cycles, the first (Cycle 1) from April to July 2016 and the second (Cycle 2) from April to July 2017, at the didactic orchard $\left(5^{\circ} 11^{\prime} \mathrm{S}, 37^{\circ} 20^{\prime} \mathrm{W}, 18 \mathrm{~m}\right.$ altitude) of Federal Rural University of Semiarid (UFERSA), Mossoró city, Rio Grande do Norte State, Brazil. The orchard is located in the semiarid region of Brazil, where the climate is hot and dry, with an average annual temperature of 27.50 ${ }^{\circ} \mathrm{C}$, relative humidity of $68.9 \%$, cloudiness of 4.4 tenths, and rainfall of $673.9 \mathrm{~mm}$ (Sobrinho et al., 2011). Meteorological data were collected during the experiment from the weather station located at the experimental farm (Figure 1).

Fig plants were grown with $6,12,18,24$, or 30 branches per plant, or without thinning as a control, in a completely randomized block design with four replicates. Four plants were cultivated per plot, but only the two central plants were evaluated. The plants were 5 years old, and there was $2.0 \mathrm{~m}$ of space between rows and $1.5 \mathrm{~m}$ between plants. Irrigation was performed daily by one microsprinkler per plant supplying water at a 40 $\mathrm{L} \mathrm{h}^{-1}$ flow rate.

In both cycles, plants were pruned in April. After pruning, plants were fertilized with nitrogen, phosphorus, and potassium, which were supplied following soil analysis. When all the

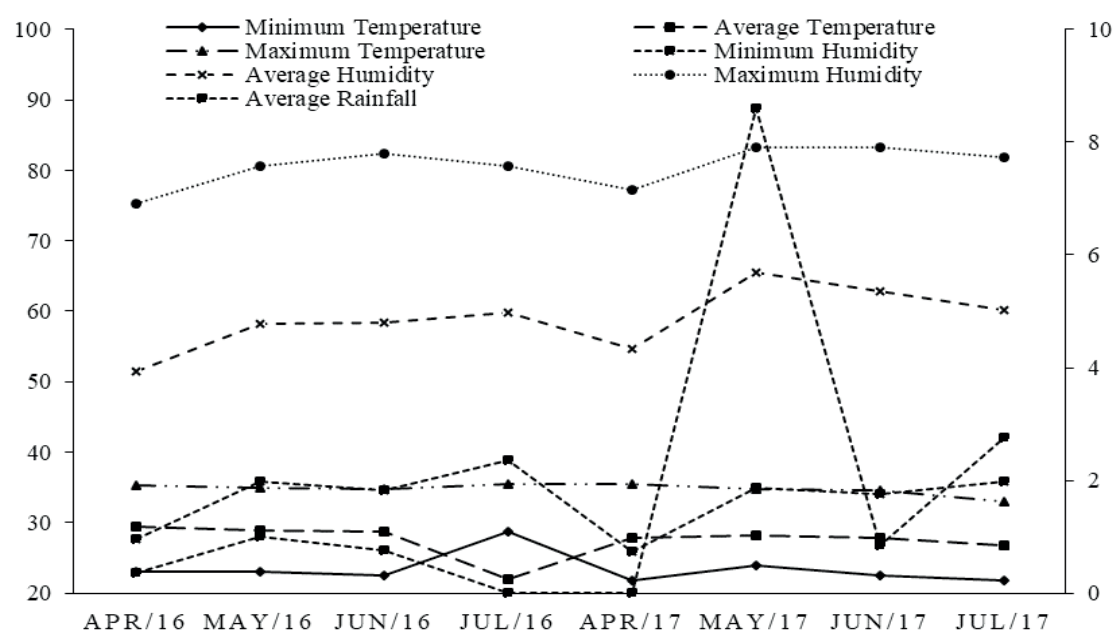

Figure 1. Temperature, relative humidity, and rainfall during two production cycles (April to July 2016 and April to July 2017) of 'Roxo de Valinhos' fig grown with different numbers of branches in the semiarid region of Brazil. UFERSA, Mossoró-RN, 2018. 
plants sprouted and showed eight pairs of leaves, the excess branches were eliminated, and only the number of branches of each treatment was maintained. Subsequently, thinning was carried out every seven days to eliminate newly sprouted branches, which may compete with the remaining branches for water, light, and nutrients.

\section{Physicochemical characteristics of fruits}

At harvest, the number of fruits per plant was determined by direct counting every three days. After harvest, fruits were weighed to determine fruit production per plant. Fruit weight was measured using a digital scale (AD 2000, Marte Científica, São Paulo, SP, Brazil, 0.01 g accuracy), and the results were expressed as g. Additionally, fruit length and diameter were measured using a digital caliper, and the results were expressed as $\mathrm{cm}$.

Pulp firmness was determined using a penetrometer (FT 327, McCormick) equipped with an $8 \mathrm{~mm}$ probe inserted $7 \mathrm{~mm}$ into the pulp. The evaluations were performed on two equidistant and opposite sides of the fruits, and values were expressed as Newtons $(\mathrm{N})$.

Then, the fruits were processed in a kitchen blender, and the puree was packed in plastic pots and stored in a freezer $\left(-20^{\circ} \mathrm{C}\right)$ to evaluate the physicochemical characteristics of the fruits. The titratable acidity (TA) was determined using $1 \mathrm{~g}$ of puree diluted in $50 \mathrm{~mL}$ distilled water and titrated with 0.1 $\mathrm{M} \mathrm{NaOH}$, using $1 \%$ phenolphthalein as a color indicator. The results were expressed as $g$ citric acid $100 \mathrm{~g}^{-1}$ fresh weight (FW) (Instituto Adolfo Lutz, 1985). The content of soluble solids (SS) was determined by direct refractometry of the puree in a digital refractometer with automatic temperature compensation (Palette, Atago ${ }^{\circledR}$, Tokyo, Japan), and the results were expressed as ${ }^{\circ} \mathrm{Brix}$ (AOAC, 1997). Then, the SS/TA ratio was calculated.

Additionally, vitamin C content was determined by titration with 2,6-dichlorophenol-indophenol solution according to AOAC (1997) and expressed as $\mathrm{mg}$ ascorbic acid $100 \mathrm{~g}^{-1} \mathrm{FW}$.

\section{Statistical analysis}

Data were submitted to analysis of variance by the $F$ test $(p<0.05)$, and means were grouped by Tukey's test $(\mathrm{p} \leq 0.05)$. All statistical analyses were performed in SISVAR software (Ferreira, 2011).

\section{Results}

As shown in Table 1, the number of branches did not affect fruit length in either Cycles 1 or 2. However, fruit diameter was higher in plants grown with six branches in Cycle $1(4.23 \mathrm{~cm})$ and those without thinning in Cycle $2(4.81 \mathrm{~cm})$.

Treatments did not affect fruit weight in either cycle, which was 29.09 and $30.23 \mathrm{~g}$ on average in Cycles 1 and 2, respectively (Table 2). In contrast, the number of fruits per plant was higher in plants with 24 branches in Cycle 1 (129.50 fruits) and those with 30 branches in Cycle 2 (167.00 fruits). Likewise, productivity was higher in plants with

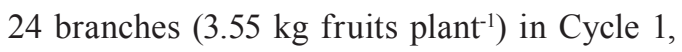
while it did not vary among treatments in Cycle 2 (3.66 kg plant ${ }^{-1}$, on average).

Table 1. Fruit length and diameter over two production cycles of 'Roxo de Valinhos' figs grown with different numbers of branches in the semiarid region of Brazil. UFERSA, Mossoró-RN, 2018.

\begin{tabular}{lcccc}
\hline \multirow{2}{*}{ Treatment } & \multicolumn{2}{c}{ Length $(\mathrm{cm})$} & \multicolumn{2}{c}{ Diameter $(\mathrm{cm})$} \\
\cline { 2 - 5 } & Cycle 1 & Cycle 2 & Cycle 1 & Cycle 2 \\
\hline Without thinning & $3.86 \mathrm{a}$ & $3.66 \mathrm{a}$ & $3.99 \mathrm{ab}$ & $4.81 \mathrm{a}$ \\
6 branches & $4.06 \mathrm{a}$ & $3.62 \mathrm{a}$ & $4.23 \mathrm{a}$ & $4.56 \mathrm{ab}$ \\
12 branches & $4.01 \mathrm{a}$ & $3.54 \mathrm{a}$ & $4.09 \mathrm{ab}$ & $4.76 \mathrm{ab}$ \\
18 branches & $3.88 \mathrm{a}$ & $3.40 \mathrm{a}$ & $4.07 \mathrm{ab}$ & $4.27 \mathrm{ab}$ \\
24 branches & $3.82 \mathrm{a}$ & $3.49 \mathrm{a}$ & $3.91 \mathrm{~b}$ & $4.16 \mathrm{~b}$ \\
30 branches & $3.85 \mathrm{a}$ & $3.31 \mathrm{a}$ & $4.07 \mathrm{ab}$ & $4.21 \mathrm{~b}$ \\
\hline
\end{tabular}

Means followed by the same letter in the column are not significantly different by Tukey's test $(\mathrm{p} \leq 0.05)$. 
Regarding the physicochemical characteristics of the fruits (Table 3), pulp firmness was higher in fruits from plants grown with 18, 24 and 30 branches in Cycle 1. On the other hand, in Cycle 2 , pulp firmness was higher in fruits from plants without thinning or those with 6 and 12 branches.

The content of soluble solids ranged from 18.10 to $20.80{ }^{\circ}$ Brix in Cycle 1, and the maximum value was obtained for plants without thinning (20.80 ${ }^{\circ}$ Brix), followed by those with 24 and 6 branches (19.00 ${ }^{\circ}$ Brix). In Cycle $2, \mathrm{SS}$ ranged from 11.30 to $12.30{ }^{\circ} \mathrm{Brix}$, with the maximum value obtained for plants with 30 branches, followed by plants with 24 and 6 branches (12.10 ${ }^{\circ}$ Brix).
The maximum titratable acidity was obtained for plants without thinning in both Cycles $1(0.21 \mathrm{~g}$

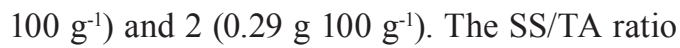
was higher in fruits from plants with 18 branches in Cycle 1 (116.57) and those with 30 branches in Cycle 2 (89.58).

The vitamin $\mathrm{C}$ content was higher in fruits from plants with 24 branches in Cycle $1(17.59 \mathrm{mg}$ $\left.100 \mathrm{~g}^{-1}\right)$ and plants with 18 branches in Cycle 2 (27.06 mg $\left.100 \mathrm{~g}^{-1}\right)$.

Table 2. Fruit weight, number of fruits per plant and yield $\left(\mathrm{kg} \mathrm{plant}^{-1}\right)$ over two production cycles of 'Roxo de Valinhos' fig plants grown with different numbers of branches in the semiarid region of Brazil. UFERSA, Mossoró-RN, 2018.

\begin{tabular}{lllllll}
\hline \multirow{2}{*}{ Treatment } & \multicolumn{2}{c}{ Fruit weight $(\mathrm{g})$} & \multicolumn{2}{c}{ Number of fruits per plant } & \multicolumn{2}{c}{ Fruit production $\left(\mathrm{kg} \mathrm{plant}^{-1}\right)$} \\
\cline { 2 - 7 } & Cycle 1 & Cycle 2 & Cycle 1 & Cycle 2 & Cycle 1 & Cycle 2 \\
\hline Without thinning & $24.90 \mathrm{a}$ & $33.88 \mathrm{a}$ & $91.50 \mathrm{~b}$ & $66.50 \mathrm{~b}$ & $2.37 \mathrm{bc}$ & $2.28 \mathrm{a}$ \\
6 branches & $26.26 \mathrm{a}$ & $33.48 \mathrm{a}$ & $77.00 \mathrm{~b}$ & $130.50 \mathrm{ab}$ & $2.06 \mathrm{c}$ & $4.07 \mathrm{a}$ \\
12 branches & $32.37 \mathrm{a}$ & $29.08 \mathrm{a}$ & $98.50 \mathrm{~b}$ & $140.75 \mathrm{ab}$ & $3.19 \mathrm{ab}$ & $4.15 \mathrm{a}$ \\
18 branches & $31.68 \mathrm{a}$ & $27.95 \mathrm{a}$ & $89.50 \mathrm{~b}$ & $121.75 \mathrm{ab}$ & $2.93 \mathrm{abc}$ & $3.41 \mathrm{a}$ \\
24 branches & $27.89 \mathrm{a}$ & $30.03 \mathrm{a}$ & $129.50 \mathrm{a}$ & $132.25 \mathrm{ab}$ & $3.55 \mathrm{a}$ & $3.61 \mathrm{a}$ \\
30 branches & $31.43 \mathrm{a}$ & $26.98 \mathrm{a}$ & $97.75 \mathrm{~b}$ & $167.00 \mathrm{a}$ & $3.18 \mathrm{ab}$ & $4.41 \mathrm{a}$ \\
\hline
\end{tabular}

Means followed by the same letter in the column are not significantly different by Tukey's test ( $\mathrm{p} \leq 0.05)$.

Table 3. Pulp firmness (N), content of soluble solids (SS), amount of vitamin C (mg ascorbic acid $100 \mathrm{~g}^{-1}$ fresh weight), titratable acidity (TA, g citric acid $100 \mathrm{~g}^{-1}$ fresh weight), and SS/TA ratio in 'Roxo de Valinhos' fig fruits from plants grown with different numbers of branches in the semiarid region of Brazil. UFERSA, Mossoró-RN, 2018.

\begin{tabular}{|c|c|c|c|c|c|c|c|c|c|c|}
\hline \multirow{2}{*}{ Treatment } & \multicolumn{2}{|c|}{ Firmness (N) } & \multicolumn{2}{|c|}{$\begin{array}{l}\text { Soluble solids } \\
\left({ }^{\circ} \text { Brix }\right)\end{array}$} & \multicolumn{2}{|c|}{$\begin{array}{c}\text { Titratable acidity } \\
(\%)\end{array}$} & \multicolumn{2}{|c|}{ Relation SS/AT } & \multicolumn{2}{|c|}{$\begin{array}{l}\text { Vitamin C } \\
\left({\left.\mathrm{mg} 100 \mathrm{~g}^{-1}\right)}^{\text {Ving }}\right.\end{array}$} \\
\hline & Cycle 1 & Cycle 2 & Cycle 1 & Cycle 2 & Cycle 1 & Cycle 2 & Cycle 1 & Cycle 2 & Cycle 1 & Cycle 2 \\
\hline $\begin{array}{l}\text { Without } \\
\text { thinning }\end{array}$ & $6.58 \mathrm{ab}$ & $7.10 \mathrm{a}$ & $20.80 \mathrm{a}$ & $11.30 \mathrm{~d}$ & $0.21 \mathrm{a}$ & $0.29 \mathrm{a}$ & $\begin{array}{l}101.50 \\
b c\end{array}$ & $38.67 \mathrm{~d}$ & $13.33 \mathrm{e}$ & $17.03 \mathrm{c}$ \\
\hline 6 branches & $5.83 \mathrm{~b}$ & $6.40 \mathrm{a}$ & $19.00 \mathrm{~b}$ & $12.10 \mathrm{~b}$ & $0.18 \mathrm{c}$ & $0.16 \mathrm{bc}$ & $104.16 \mathrm{~b}$ & $74.68 \mathrm{bc}$ & $15.85 \mathrm{~d}$ & $16.61 \mathrm{c}$ \\
\hline 12 branches & $7.13 \mathrm{ab}$ & $7.22 \mathrm{a}$ & $18.10 \mathrm{c}$ & $11.60 \mathrm{c}$ & $0.19 \mathrm{bc}$ & $0.14 \mathrm{~cd}$ & $94.06 \mathrm{~d}$ & $78.88 \mathrm{bc}$ & $16.54 \mathrm{c}$ & $20.69 \mathrm{~b}$ \\
\hline 18 branches & $8.26 \mathrm{a}$ & $4.97 \mathrm{~b}$ & $18.90 \mathrm{~b}$ & $12.05 \mathrm{~b}$ & $0.16 \mathrm{~d}$ & $0.14 \mathrm{~cd}$ & $116.57 \mathrm{a}$ & $83.20 \mathrm{ab}$ & $15.85 \mathrm{~d}$ & $27.06 \mathrm{a}$ \\
\hline 24 branches & $8.41 \mathrm{a}$ & $5.80 \mathrm{ab}$ & $19.00 \mathrm{~b}$ & $12.10 \mathrm{~b}$ & $0.192 \mathrm{ab}$ & $0.17 \mathrm{~b}$ & $96.31 \mathrm{~cd}$ & $70.34 \mathrm{c}$ & $17.59 \mathrm{a}$ & $20.34 \mathrm{~b}$ \\
\hline 30 branches & $8.42 \mathrm{a}$ & $6.70 \mathrm{ab}$ & $18.45 \mathrm{bc}$ & $12.30 \mathrm{a}$ & $0.185 \mathrm{c}$ & $0.13 \mathrm{~d}$ & $\begin{array}{l}99.80 \\
\text { bcd }\end{array}$ & $89.58 \mathrm{a}$ & $16.70 \mathrm{~b}$ & $20.81 \mathrm{~b}$ \\
\hline
\end{tabular}

Means followed by the same letter in the column are not significantly different by Tukey's test $(\mathrm{p} \leq 0.05)$. 


\section{Discussion}

The results agree with those of Freitas et al. (2015) for figs grown in Limoeiro do Norte, Ceará state, Brazil, where fruits were $5.29 \mathrm{~cm}$ in length and $4.58 \mathrm{~cm}$ in diameter. According to Almeida \& Martin (1997), the high temperature in the semiarid region stimulates fruit growth, increasing fruit length and diameter during development.

The fruit weight we obtained (27.89-33.88 g) was lower than that reported by Lajús (2004) for 'Roxo de Valinhos' figs; in their study, plants grown with 6 and 12 branches produced fruits with average weights of $52.4 \mathrm{~g}$ and $51.8 \mathrm{~g}$, respectively. Campagnolo et al. (2009) found that plants grown with 6 branches produced 156.80 fruits, while in those with 12 branches, the number of fruits increased to 189.94 , which was higher than the number of fruits per plant obtained in our study.

Caetano et al. (2005) observed that the number of fruits per branch decreased as the number of branches per plant increased from 16 to 32 . According to the authors, such a reduction was a consequence of shading caused by the branches, which reduced the differentiation of reproductive buds. Moreover, changes in climatic conditions, such as temperature, air humidity, photosynthetic radiation, and atmospheric composition, may influence the phenological, vegetative and reproductive aspects of fig trees (Chaves, 2003).

Regarding the physicochemical characteristics of fruits, pulp firmness in the present study $(4.97-8.42 \mathrm{~N})$ was higher than that $(2.36 \mathrm{~N})$ found by Freitas et al. (2015), who examined fruits produced under an open-air cultivation system in Chapada do Apodi, Ceará State, Brazil. Sales Júnior (2014) explained that changes in pulp firmness are associated with changes in pectic substances present in the cell wall and middle lamella. Pectate and pectinate contents increase as total pectin decreases during fruit ripening, which reduces pulp firmness.
The content of soluble solids (SS) was higher in Cycle 1 (18.10-20.80 ${ }^{\circ}$ Brix) than in Cycle 2 (11.60-12.30 ${ }^{\circ}$ Brix) (Table 3). The range in Cycle 2 was similar to that obtained by Chaves (2003) at 14.6 to $15.9^{\circ} \mathrm{Brix}$. SS represents water-soluble compounds in fruits, such as sugars, vitamins, acids, amino acids, and pectins, whose concentrations depend on the fruit maturation stage and generally increase during ripening by polysaccharide degradation (Chitarra \& Chitarra, 2005). Moreover, SS in fruits varies according to cultivar, edaphoclimatic conditions, and harvest season (Carvalho et al., 2001).

According to Gonçalves et al. (2006), figs for fresh consumption must present $0.720 \%$ titratable acidity at harvest time. In this work, the titratable acidity was between 0.162 and $0.205 \%$. Other studies also found similar levels of titratable acidity in figs produced in the Brazilian semiarid region. Freitas et al. (2015) reported a titratable acidity of $0.161 \%$ in figs produced in Chapada do Apodi. According to Chitarra (1998), fruit acidity is affected by changes in the concentration of organic acids during fruit growth and differs across fruit types. This variation in acidity is due to several factors, including maturation stage, nutrition, climatic conditions, and cultivar (Alvarenga, 2004).

Additionally, the SS/TA ratio is one of the most commonly used parameters to evaluate fruit taste. High levels of SS/TA are associated with mild taste due to the combination of sugars and acids, whereas low levels of SS/TA are associated with an acidic taste that is less accepted (Pacheco et al., 1997).

Freitas et al. (2015) cultivated 'Roxo de Valinhos' figs under different growing conditions in Chapada do Apodi, Ceará, Brazil, and harvested fruits with a vitamin C content of $10.39 \mathrm{mg} 100$ ascorbic acid $\mathrm{g}^{-1}$ fresh weight, which was lower than that obtained in our study (13.33-27.06 mg $\left.100 \mathrm{~g}^{-1}\right)$. Figs do not have high vitamin $\mathrm{C}$ levels compared to other fruits, such as cashew and acerola (Freitas et al. 2015). According to Gabas 
et al. (2003), the vitamin $\mathrm{C}$ content in fruits is affected by several factors, such as $\mathrm{pH}$, light, $\mathrm{O}_{2}$, temperature, and air relative humidity.

\section{Conclusions}

Branch thinning in fig (Ficus carica L.) increases fruit production under semiarid conditions. Plants grown with $12,18,24$, and 30 branches in the
Brazilian semiarid region produce more fruits and heavier fruits than plants without thinning. Additionally, branch thinning increases pulp firmness, the content of soluble solids, and the amount of vitamin $\mathrm{C}$ in fruits. Plants grown with 24 branches produce fruits with greater uniformity in weight, number, and production between cycles.

\section{Resumen}

V. Mendonça, F.S.O. Silva, A.A. Alves, E.G.P. Martins, E.C. dos. Santos, W.C. Farias, y E.C. Pereira. 2021. Comportamiento agronómico de plantas de higo cultivadas con diferente número de ramas. Int. J. Agric. Nat. Resour. 14-20. La producción y calidad del higo están asociadas con el número de ramas por planta y pueden variar entre las regiones según las condiciones climáticas y el manejo del cultivo. En este trabajo se estudió la influencia del número de ramas por planta en la producción y calidad del fruto del higo 'Roxo de Valinhos' en condiciones semiáridas. El experimento se llevó a cabo en el huerto didáctico de la Universidad Federal Rural del Semiárido (UFERSA), ciudad de Mossoró, estado de Rio Grande do Norte, Brasil. Las plantas de higo se cultivaron con $6,12,18$ o 30 ramas en un diseño de bloques completamente casualizados con cuatro repeticiones y cuatro plantas por parcela. También se cultivaron plantas sin eliminación de rama como tratamiento control. Se evaluó el número de frutos por planta, productividad, longitud, diámetro y peso del fruto. También se analizó la firmeza del fruto, acidez titulable (TA), contenido de sólidos solubles (SSC), índice de maduración (SSC / TA) y vitamina C. Los resultados mostraron que las plantas cultivadas con 12, 18 y 24 ramas produjeron frutos con mayor peso, número de frutos por rama, número de frutos por planta y, por tanto, fueron más productivas. Además, los frutos mostraron alto contenido de vitamina $\mathrm{C}$ e índice de maduración.

Palabras clave: Ficus carica L., fruticultura, poda, poscosecha, productividad.

\section{References}

Almeida, M.E.M., \& Martin, Z.J. (1997). A industrialização do figo. Informe Agropecuário, 18:4-21.

Alvarenga, M. A. R. (2004). Tomate: produção em campo, casa de vegetação e em hidroponia. Lavras: UFLA. 400 p.

AOAC. (1997). Official methods of analysis. 16th ed., 3rd rev. Gaitherburg: AOAC International, $2: 1-43$.
Caetano, L.C.S., Carvalho, A.J.C., Campostrine, E., Sousa, E.F., Murakami, K.R.N., \& Cereja, B.S. (2005). Efeito do número de ramos produtivos sobre o desenvolvimento da área foliar e produtividade da figueira. Revista Brasileira de Fruticultura, 27:426-429. doi: 10.1590/s010029452005000300021

Campagnolo, M.A., Pio, R., Dalastra, I.M., Chagas, E.A., Guimarães, V.F., \& Dalastra, G.M. (2009). Sistema desponte na produção de figos verdes 
'Roxo de Valinhos'. Ciência Rural, 40:25-29. doi: 10.1590/s0103-84782009005000219

Carvalho, H.A., Chitarra, M.I.F., Chitarra, A.B., \& Carvalho, H.S. (2001). Efeito da atmosfera modificada sobre componentes da parede celular da goiaba. Ciência e Agrotecnologia, 25:605-615.

Chaves, A. (2003). Figueira cv. Roxo de Valinhos submetida a diferentes épocas de poda e número de ramos combinado com espaçamentos, em ambiente protegido. 110 p. Doctoral dissertation - Faculdade de Agronomia e Medicina Veterinária, Universidade de Passo Fundo, Passo Fundo, Brazil.

Chitarra, M.I.F. (1998). Colheita e qualidade de produtos vegetais. Poços de Caldas UFLA/SBEA, $58 \mathrm{p}$.

Chitarra, M.I.F., \& Chitarra, A.B. (2005). Pós-colheita de frutos e hortaliças: fisiologia e manuseio. 2th Ed. Lavras: UFLA.

Ferreira, D.F. (2011). Sisvar: A computer statistical analysis system. Ciência e Agrotecnologia, 35:1039-1042. doi: 10.1590/s141370542011000600001

Freitas, R.N.S., Souza, P.A., Silva, M.E.T., Silva, F.L., \& Maracaja, P.B. (2015). Caracterização pós-colheita de figos (Ficus carica L.) produzidos sob diferentes condições de cultivo na Chapada do Apodi-CE. Revista Verde, 10:43-46. doi: 10.18378/rvads.v10i1.3316

Gabas, A.L, Telis-Romero, C., \& Menegalli, F.C. (2003). Cinética de degradação do ácido ascórbico em ameixas liofilizadas. Ciência e Tecnologia de Alimentos, 23:66-70. doi: 10.1590/s010120612003000400013

Giacobbo, C.L., Picolotto, L., Krüger, L.R., Parisotto, E., Tibola, C., \& Fachinello, J.C. (2007). Cultivo da figueira conduzida em quatro diferentes densidades de plantio. Revista Brasileira de Agrociência, 13:43-46.

Gonçalves, C.A.A., Lima, L.C.O., Lopes, P.S.N., \& Souza, M.T. (2006). Poda e sistemas de condução na produção de figos verdes. Pesquisa Agropecuária Brasileira, 41:955-961. doi: 10.1590/ s0100-204x2006000600009
Instituto Adolfo Lutz. (1985). Normas Analiticas do Instituto Adolfo Lutz. Métodos químicos e físicos para análise de alimentos. 3rd Ed. São Paulo: IMESP, 1:183.

Kim, B.S., Gu, M., Cho, K.C., Jung, S.K., \& Choi, H.S. (2017). Effect of tree and branch thinning on growth, yield, and fruit quality of persimmon trees in a high-density orchard. The Journal of Horticultural Science and Biotechnology, 92(4):432-438.

Lajús, C.R. (2004). Desenvolvimento e produção da figueira cv. Roxo de Valinhos em ambiente protegido, submetida a diferentes épocas de poda e condução. 146 p. Masters dissertation, Faculdade de Agronomia e Medicina Veterinária, Universidade de Passo Fundo, Brazil.

Pacheco, M.A.S.R., Fonseca, Y.S.K., Dias, H.G.G., Cândido, V.L.P., Pazinato, B.C., \& Galhardo, R.C. (1997). Processamento artesanal do tomate. Campinas: Coordenadoria de Assistência Técnica Integral. $30 \mathrm{p}$.

Sales Júnior, L.A. (2014). Climatização de frutos de bananeiras com características de resistência à Sigatoka-Negra. 74 p. Masters dissertation, Universidade Federal do Paraná, Curitiba, Brazil.

Silva, F.S.O., Pereira, E.C., Mendonça, V., Câmara, F.M.M., Pereira, G.A., \& Santos, E.C. (2017). Postharvest quality of 'Roxo de Valinhos' fig fruits grown in semi-arid conditions. Comunicata Scientiae, 8:93-98. doi: 10.14295/cs.v8i1.1546

Sobrinho, J.E., Pereira, V.C., Oliveira, A.D., Santos, W.O., Silva, N.K.C., and Maniçoba, R.M. (2011). Climatologia da precipitação no município de Mossoró-RN. Período: 1900-2010. In: XVII Congresso Brasileiro de Agrometeorologia, 2011, Guarapari.

Yang, X., Guo, J.L., Ye, J.Y., Zhang, Y.X., \& Wang, W. (2015). The effects of Ficus carica polysaccharide on immune response and expression of some immune-related genes in grass carp, Ctenopharyngodon idella. Fish \& shellfish immunology, 42:132-137. doi: 10.1016/j.fsi.2014.10.037 